\title{
PRENATAL DIAGNOSIS OF MORQUIO DISEASE TYPE A USING A SIMPLE FLUOROMETRIC ENZYME ASSAY
}

\author{
H. ZHAO*\|, O. P. VAN DIGGELEN*, R. THOOMES*, J. HUIJMANS $\dagger$, E. YOUNG $\ddagger$, \\ T. MAZURCZAK $\oint$ AND W. J. KLEIJER* \\ *Department of Clinical Genetics, University Hospital, Erasmus University, Rotterdam, The \\ Netherlands; † Department of Pediatrics, Sophia Children's Hospital Erasmus University, Rotterdam, \\ The Netherlands; $\ddagger$ Department of Clinical Biochemistry, Hospital for Sick Children, Great Ormond \\ Street, London, U.K.; \$Department of Genetics, National Research Institute of Mother and Child, \\ Warsaw, Poland
}

\section{SUMMARY}

A new fluorogenic substrate, 4 methylumbelliferyl $\beta$-D-6-sulphogalactoside, was used for the assay of galactose-6-sulphate sulphatase activity in chorionic villi, cultured villus cells, and amniocytes. The fluorometric assay is much more convenient than the conventional assay using radiolabelled, sulphated oligosaccharides. Both types of substrate were used in the prenatal diagnosis of three pregnancies at risk for Morquio type A disease using amniocytes. These enzyme tests, as well as electrophoresis of glycosaminoglycans in the amniotic fluid, indicated affected fetuses in two pregnancies and a non-affected fetus in one.

KEY words Prenatal diagnosis Chorionic villi Morquio diasease, type A Mucopolysaccharidosis, type IV A Galactose-6-sulphate sulphatase

\section{INTRODUCTION}

Prenatal diagnosis of Morquio disease type A (Mucopolysaccharidosis type IV A (MPS IV A)) has been made by demonstrating the deficiency of $\mathrm{N}$-acetylgalactosamine-6-sulphate sulphatase (Figura et al., 1982). Subsequently it was shown that most types of MPS, including MPS IV A, can also be demonstrated prenatally by electrophoresis of glycosaminoglycans (GAG) in amniotic fluid (Mossman and Patrick, 1982).

The defective sulphatase in MPS IV A has activity towards oligosaccharides with a terminal $N$-acetylgalactosamine-6-sulphate (GalNAc-6S) (Matalon et al., 1974; Singh et al., 1976) or galactose-6-sulphate (Gal-6S) (Glössl and Kresse, 1982; Yukata et al., 1982), which explains the defect in the catabolism of both chondroitin6-sulphate and keratan sulphate in MPS IV A. The commonly used method for the diagnosis of MPS IV A is the technically difficult GalNAc-6S sulphatase assay using a radiolabelled trisaccharide (Glössl et al., 1981). We have synthesized 4-methylumbelliferyl (4MU)-6-sulphogalactoside and have shown that this is an excellent substrate for the assay of Gal-6S sulphatase in cultured fibroblasts and in leukocytes (Van Diggelen et al., 1990). In this assay, the fluorochrome $4 \mathrm{MU}$ is

Present address: Department of Medical Genetics, Harbin Medical University, Harbin, China. Addressee for correspondence: Dr W. J. Kleijer, Department of Clinical Genetics, Erasmus University, P.O. Box 1738, Rotterdam, The Netherlands. 
released after the successive action of Gal-6S sulphatase and endogenous $\beta$ galactosidase which is present in large quantities in the cell types investigated. In this report we describe optimal conditions for the assay of Gal-6S sulphatase and the ranges of activity in chorionic villi $(\mathrm{CV})$, cultured $\mathrm{CV}$ cells and amniocytes, and in fetal liver, brain, and muscle. This fluorometric enzyme assay was applied in retrospective as well as in prospective prenatal analyses in pregancies at risk.

\section{PATIENTS AND METHODS}

Prenatal analyses were performed in the pregnancies of three mothers each of whom had a previous child with MPS IV A. Amniotic fluid cells from pregnancy 1 were kindly made available to us by Dr G. T. N. Besley (Edinburgh) for retrospective analysis. Amniocentesis in the 17th week of pregnancies 2 and 3 was performed in Warsaw, where also chromosome analyses were done; part of the fluid was sent to Rotterdam for cell cultivation and biochemical analysis.

Chorionic villi were obtained by transcervical aspiration from pregnancies at risk for chromosomal disorders or after elective termination of pregnancy. After dissection and microscopic selection the villi were washed in saline and stored at $-70^{\circ} \mathrm{C}$ until use. Cells from minced and collagenase-treated villi were cultured in Ham's F12 and after the beginning of cell growth in Ham's F10 both with 5 per cent FCS and with 4 per cent Ultroser G (IBF, France).

Amniotic fluid cells and fibroblasts were cultivated in Ham's F10 medium with 20 and 15 per cent FCS, respectively; they were harvested 7 days after the previous trypsinization and homogenized by sonication in water. Chorionic villi and other fetal tissues were homogenized in a Potter tube before sonication.

For the standard Gal-6S sulphatase assay, the cell or tissue homogenate was centrifuged for $10 \mathrm{~min}$ at $12000 \mathrm{rpm}$ and the supernatant was dialysed overnight at $4^{\circ} \mathrm{C}$ against $0.01 \mathrm{~mol} / 1$ sodium acetate buffer, $\mathrm{pH} 6.0$, containing $0.1 \mathrm{~mol} / 1$ sodium chloride. The substrate, 4MU-Gal-6S, was synthesized as described by Van Diggelen et al. (1990); it is commercially available (Melford Laboratories Ltd, Ipswich, U.K.). The reaction mixture $(30 \mu \mathrm{l})$ consisted of $10 \mu \mathrm{l}$ of dialysed supernatant containing $20 \mu \mathrm{g}$ of protein and $20 \mu \mathrm{l}$ of $1 \mathrm{mM} 4 \mathrm{MU}-\mathrm{Gal}-6 \mathrm{~S}$ in $0 \cdot 1 \mathrm{~mol} / \mathrm{l}$ sodium acetate buffer, $\mathrm{pH} 4 \cdot 3$, with $0 \cdot 1 \mathrm{~mol} / \mathrm{l}$ sodium chloride. After incubation for $17 \mathrm{~h}$ at $37^{\circ} \mathrm{C}$, the reaction mixture was supplemented with $10 \mu \mathrm{l}$ supernatant from MPS IV A fibroblasts and $2 \mu \mathrm{l}$ of $2 \mathrm{~mol} / \mathrm{l}$ sodium phosphate buffer, $\mathrm{pH} \mathrm{4} 3$, and incubation was continued for $2 \mathrm{~h}$ at $37^{\circ} \mathrm{C}$ to complete the hydrolysis of $4 \mathrm{MU}-\beta$-galactoside.

The reaction was stopped by the addition of $200 \mu \mathrm{l}$ of $0.5 \mathrm{~mol} / \mathrm{l}$ sodium carbonate buffer, $\mathrm{pH} 10 \cdot 7$, and the fluorescence of free $4 \mathrm{MU}$ was measured in a Fluoroscan fluorometer (Titertek). The measurement was corrected using a blank value obtained by incubating the complete reaction mixture in the presence of $0.1 \mathrm{~mol} / \mathrm{l}$ sodium phosphate buffer, $\mathrm{pH} 4 \cdot 3$, which completely inhibits Gal-6S sulphatase (Van Diggelen et al., 1990).

Protein was determined using the BCA method (Smith et al., 1985). One- and twodimensional electrophoresis of GAG was performed as described before (Mossman and Patrick, 1982). 

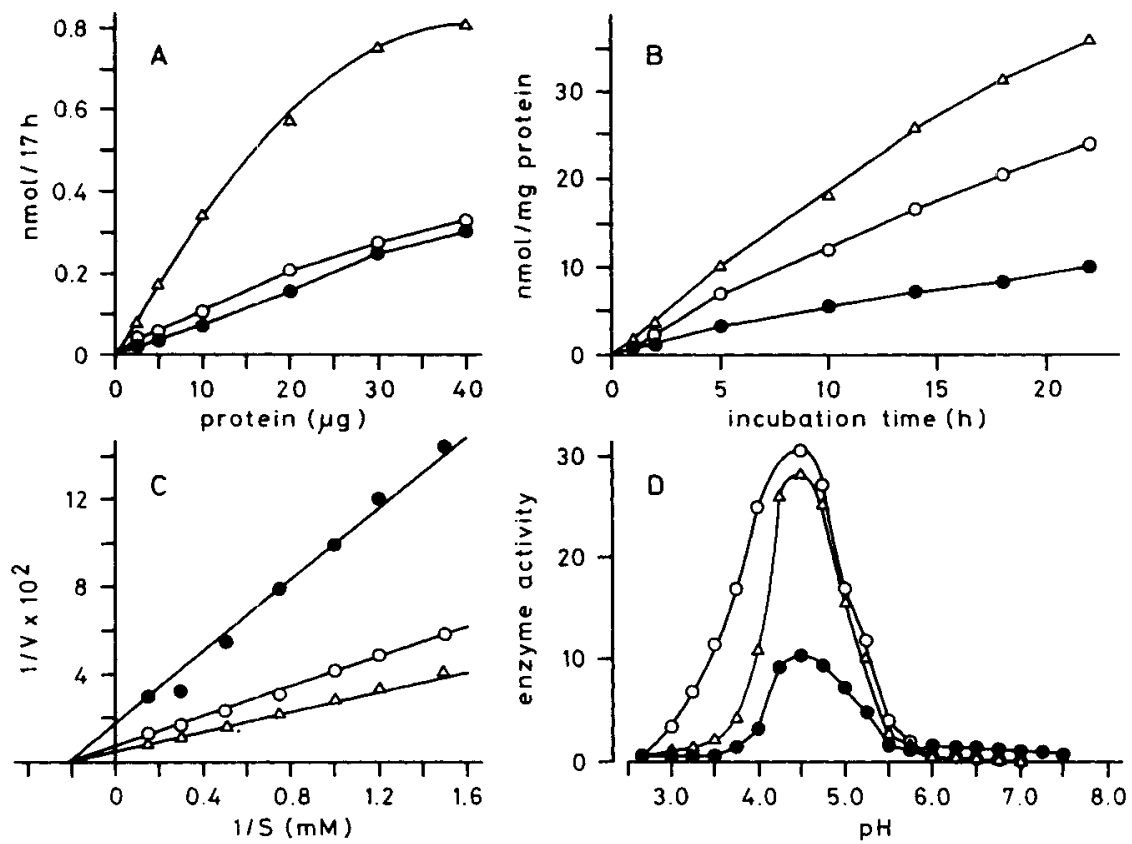

Figure 1. Kinetic properties of galactose-6-sulphate sulphatase in chorionic villi $(\bullet)$, cultured chorionic villus cells $(O)$, and amniocytes $(\triangle)$. (A) Protein dependency; (B) time course; (C) Lineweaver-Burk plot, $S=$ substrate concentration ( $4 \mathrm{MU}-\mathrm{Gal}-6 \mathrm{~S} ; \mathrm{mM}$ ), $V=$ specific activity (nmol $/ 17 \mathrm{~h}^{-1} / \mathrm{mg}$ protein);

(D) $\mathrm{pH}$ dependency

\section{RESULTS}

\section{Enzyme assay conditions}

Various conditions for the assay of Gal-6S sulphatase activity in cultured cells and in fetal tissues were investigated. The results for cultured amniocytes and CV cells and for uncultured CV are shown in Figure 1. Similar results have been obtained for cultured fibroblasts (Van Diggelen et al., 1990) and for fetal tissues (liver, brain, muscle; not shown). The enzymatic reaction proceeded almost linearly with the amount of cellular protein (up to $20 \mu \mathrm{g}$ ) in the incubation mixture and with the incubation time, after a lag time of $30 \mathrm{~min}$, up to $17 \mathrm{~h}$. The $K_{\mathrm{m}}$ for all cell types and tissues was estimated as $7 \mathrm{~mm}$; the optimum $\mathrm{pH}$ in the cultured cells and in CV was $\mathrm{pH} 4.5$. At $\mathrm{pH} 7.0$ or higher, slight activity was only found in $\mathrm{CV}$; this suggests that neutral sulphatases do not interfere in the assay. Gal-6S sulphatase activity in the centrifuged CV homogenate is completely inhibited by $0.05 \mathrm{~mol} / \mathrm{l}$ phosphate, which excludes interference of phosphate-resistant sulphatases such as arylsulphatase $C$. Based on these results, standard conditions were chosen for the enzyme assay in all cell types and tissues as described in Patients and Methods. A substrate concentration $(0.67 \mathrm{mmol} / \mathrm{l})$ far below the $K_{\mathrm{m}}$ value was chosen for practical reasons (see I)iscussion).

The ranges of Gal-6S sulphatase activity in fetal cells and tissues were established using the standard assay conditions and were compared with those in cultured skin fibroblasts of controls and of MPS IV A patients (Table 1). The Gal-6S sulphatase 
Table 1. Galactose-6-sulphate sulphatase activity in fetal cells and tissues

\begin{tabular}{|c|c|c|}
\hline \multirow{2}{*}{$\begin{array}{l}\text { Cells or } \\
\text { tissue }\end{array}$} & \multicolumn{2}{|c|}{$\begin{array}{c}\text { Enzyme activity } \\
\text { (nmol } / 17 \mathrm{~h} / \mathrm{mg} \text { protein) }\end{array}$} \\
\hline & Controls* & Morquio A \\
\hline $\begin{array}{l}\text { Skin } \\
\text { fibroblasts }\end{array}$ & $\begin{array}{c}38 \cdot 9( \pm 13 \cdot 8) \\
19 \cdot 9-78 \cdot 8 \\
(n=25)\end{array}$ & $\begin{array}{c}0.35( \pm 0.18) \\
0.03-0.60 \\
(n=8)\end{array}$ \\
\hline $\begin{array}{l}\text { Amniotic fluid } \\
\text { cells }\end{array}$ & $\begin{array}{c}21 \cdot 6( \pm 5 \cdot 3) \\
13 \cdot 2-32 \cdot 9 \\
(n=21)\end{array}$ & $\begin{array}{c}0 \cdot 2 ; 1.0 \\
(n=2) \\
\text { (see Table 2) }\end{array}$ \\
\hline $\begin{array}{l}\text { Cultured chorionic } \\
\text { villus cells }\end{array}$ & $\begin{array}{c}22 \cdot 9( \pm 4 \cdot 1) \\
17 \cdot 7-29 \cdot 9 \\
(n=19)\end{array}$ & - \\
\hline $\begin{array}{l}\text { Chorionic } \\
\text { villi }\end{array}$ & $\begin{array}{c}12 \cdot 6( \pm 3 \cdot 9) \\
8 \cdot 0-20 \cdot 3 \\
(n=21)\end{array}$ & - \\
\hline Fetal liver & $3 \cdot 6-9 \cdot 4 \quad(n=3)$ & $0.02 \dagger$ \\
\hline Fetal brain & $4 \cdot 2-5 \cdot 9 \quad(n=3)$ & $0.26+$ \\
\hline Fetal muscle & $8 \cdot 5-15 \cdot 0(n=3)$ & $0.29+$ \\
\hline
\end{tabular}

*Mean $\pm S D$ and ranges.

†Affected fetus diagnosed in 1980 (Figura et al., 1982).

activities in amniocytes and cultured CV cells are approximately half the activity in fibroblasts, whereas the activity in (uncultured) CV is about one-third of the fibroblast level. These levels of activity can be measured with high accuracy and are far above the very low levels which are found in fibroblasts of MPS IV A patients ( 1 per cent or less of the level in controls).

Gal-6S sulphatase also has considerable activity in fetal liver, brain, and muscle, even after storage for $4-10$ years at $-70^{\circ} \mathrm{C}$. In contrast, very low activity was shown in the tissues of a fetus with MPS IV A disease, i.e., less than 3 per cent of the mean activity in the controls (Table 1 ); a reference enzyme ( $\beta$-galactosidase) had normal activity in these tissues (data not shown).

In the present assay, the first incubation period of $17 \mathrm{~h}$ was followed by a period of $2 \mathrm{~h}$ in which Gal-6S sulphatase was inhibited and the remaining 4MU- $\beta$-galactoside was hydrolysed by extra supplied $\beta$-galactosidase (see Patients and Methods). Omission of the latter step led to an apparent reduction of Gal-6S sulphatase activity of 0-10 per cent for cultured amniocytes and CV cells, 5-20 per cent for uncultured $\mathrm{CV}$, and 20-50 per cent for the few samples of fetal tissue tested (data not shown).

\section{Prenatal diagnosis}

Table 2 shows the results of prospective and retrospective studies of three pregnancies at risk for MPS IV A. Skin fibroblasts of the probands and their parents 
Table 2. Galactose-6-sulphate sulphatase activity in amniotic fluid cells from three pregnancies at risk for Morquio disease type A

\begin{tabular}{lc}
\hline & $\begin{array}{c}\text { MU-Gal-6S sulphatase } \\
\text { (nmol/17 h/mg protein) }\end{array}$ \\
\hline Amniotic fluid cells & \\
Pregnancy 1 & $1 \cdot 0$ \\
Pregnancy 2 & $0 \cdot 6$ \\
Pregnancy 3 & $12 \cdot 4-33 \cdot 2$ \\
Controls (range) & $(n=21)$ \\
& \\
Fibroblasts & \\
Family 2: & $0 \cdot 09$ \\
Affected child & $14 \cdot 3 ; 19 \cdot 8$ \\
Mother; father & \\
Family 3: & $0 \cdot 00$ \\
Affected child & $19 \cdot 0 ; 12 \cdot 5$ \\
Mother; father & $19 \cdot 9-78 \cdot 8$ \\
Controls (range) & $(n=25)$ \\
& \\
\hline
\end{tabular}

were investigated and showed a profound deficiency of Gal-6S sulphatase activity in the patients and a reduced level in the four obligate heterozygous parents (families 2 and 3).

In pregnancy 1 , the diagnosis of an affected fetus was made following the demonstration by one-dimensional electrophoresis of an abnormal GAG pattern in the amniotic fluid and by the deficiencies of Gal-6S sulphatase and GalNAc-6S sulphatase in the cultured amniocytes using radiolabelled substrates (Drs D. Broadhead and G. Besley, Edinburgh). In retrospect, we have confirmed the deficiency of Gal-6S sulphatase in these amniocytes with the $4 \mathrm{MU}$ Gal-6S substrate; the level of residual activity was less than 2 per cent of controls. In the second pregnancy, MPS IV A was excluded by finding a normal pattern in the electrophoresis of GAG in amniotic fluid and a reduction of GalNAc-6S sulphatase (B. Poorthuis, Leiden) to a level which suggested heterozygosity. Subsequent testing of these cells, using the fluorometric assay, confirmed the diagnosis of a heterozygous fetus. The child was recently born and is healthy. In the third pregnancy at risk, the fluorometric test was applied for prospective prenatal diagnosis. A complete deficiency of Gal-6S sulphatase in the amniocytes indicated unequivocally that the fetus was affected, although two-dimensional electrophoresis had not shown clear evidence of keratan sulphate in the amniotic fluid. One-dimensional electrophoresis, however, showed a band running ahead of chondroitin sulphate in the position of keratan sulphate. When, 3 weeks after amniocentesis, the diagnosis of an affected fetus was reported, the pregnancy had already been terminated because of trisomy 21; no tissues or cells had been stored for confirmatory enzyme studies. 


\section{DISCUSSION}

We have recently reported the synthesis of 4MU-Gal-6S and its use in the diagnosis of MPS IV A in patients and carriers, using cultured fibroblasts and leukocytes (Van Diggelen et al., 1990). The investigations described here show that the fluorogenic substrate is similarly effective in the assay of Gal-6S sulphatase in cultured amniocytes, CV cells, uncultured CV, and several (fetal) tissues.

Gal-6S sulphatase activity in CV and amniocytes is lower than in fibroblasts, but it is sufficiently high for accurate measurement in small amounts of material. In the present investigations, a sub-optimal substrate concentration was used because of the limited amount of substrate available in the early stage of the studies; the enzyme activity may be considerably increased by raising the substrate concentration to a value above the $K_{\mathrm{m}}$. The measurement of true Gal-6S sulphatase activity depends on the complete hydrolysis of the desulphated, intermediate reaction product $4 \mathrm{MU}-\mathrm{Gal}$. This is largely (i.e., $80-100$ per cent) accomplished by endogenous $\beta$ galactosidase in $\mathrm{CV}$ and amniocytes; to guarantee complete release of $4 \mathrm{MU}$, after stopping the sulphatase action, a second incubation may be performed for $2 \mathrm{~h}$ with additional $\beta$-galactosidase. The specificity of the present assay for $\mathrm{Gal}-6 \mathrm{~S}$ sulphatase activity is demonstrated by the complete absence of activity in fibroblasts and amniocytes of patients. For CV, such direct proof of the specificity of the test has not been possible because defective $C V$ have so far not been available. Arylsulphatase $C$, which has high activity in CV (in contrast to fibroblasts and amniocytes), might be anticipated as a source of interference in any sulphatase assay (Kleijer et al., 1984; Fensom et al., 1988). However, its inactivity toward the substrate was shown by $\mathrm{pH}$ dependence and phosphate inhibition studies.

Prenatal diagnosis for MPS IV A has not been reported after CV sampling, but several prenatal analyses have been made after amniocentesis: e.g., in London/ Edinburgh 12 pregnancies at risk were tested with four affected fetuses and in Rotterdam five cases with three affected fetuses. In all of the affected pregnancies from London/Edinburgh and in the present case 3 (Table 2), an abnormal GAG pattern in the amniotic fluid was clearly shown by one-dimensional electrophoresis whereas two-dimensional electrophoresis failed to separate keratan sulphate from the normally occurring constituent chondroitin sulphate. In the remaining two affected cases from Rotterdam, two-dimensional electrophoresis showed an abnormally large spot at or near the position of chondroitin and keratan sulphate. These results confirm the suggestion by Mossman and Patrick (1982) that some difficulty might be experienced in the interpretation of the Morquio two-dimensional electrophoresis pattern and that a better resolution might be obtained by one-dimensional electrophoresis.

GAG electrophoresis is a valuable ancillary method for prenatal diagnosis of MPS IV A disease if amniotic fluid is the available material for study. However, since CV sampling allows a safe and reliable prenatal diagnosis for many disorders already in the first trimester (Kleijer, 1986) this method has become the method of choice whenever possible. The fluorometric assay of Gal-6S sulphatase described provides a simple and sensitive method for prenatal diagnosis of MPS IV A; its reliability was shown here by the prospective and retrospective analyses of amniotic fluid cells from three pregnancies at risk. Our studies also suggest that this enzyme 
assay should provide an efficient and reliable method of prenatal diagnosis in the first trimester of pregnancy by direct analysis of CV and cultured CV cells.

\section{ACKNOWLEDGEMENTS}

We thank Dr G. T. N. Besley for sending amniotic fluid cells from a Morquio A affected pregnancy and Dr B. J. H. M. Poorthuis for performing enzyme assays with radiolabelled substrate.

\section{REFERENCES}

Fensom, A.H., Marsh. J., Jackson, M., McGuire, M., Vimal, C., Nicolaides, K., Sheridan, R. (1988). First-trimester diagnosis of metachromatic leucodystrophy, Clin. Genet., 34, $122-125$.

Figura. K., van de Kamp, J.J., Niermeijer, M.F. (1982). Prenatal diagnosis of Morquio's disease type A ( $N$-acetylgalactosamine 6-sulphate sulphatase deficiency), Prenat. Diagn., 2 , 67-69.

Glössl, J., Kresse, H. (1982). Impaired degradation of keratan sulphate by Morquio A fibroblasts, Biochem. J., 203, 335-338.

Glössl, J., Maroteaux, P., DiNatale, P., Kresse, H. (1981). Different properties of residual $N$-acetylgalactosamine-6-sulphate sulphatase in fibroblasts from patients with mild and severe forms of Morquio disease type A, Pediatr. Res., 15, 976-978.

Kleijer. W.J. (1986). First-trimester diagnosis of genetic metabolic disorders, Contrib. Gynecol. Obstet., 15, 80-89.

Kleijer. W.J., van Diggelen, O.P., Janse, H.C., Galjaard, H., Dumez, Y., Boue, J. (1984). First-trimester diagnosis of Hunter syndrome on chorionic villi, Lancet, ii, 472.

Matalon, R., Arbogast, B., Justice, P., Brandt, I.K., Dorfman, A. (1974). Morquio's syndrome: deficiency of a chondroitin sulphate $N$-acetylgalactosamine-6-sulfate sulfatase, Biochem. Biophys. Res. Commun., 61, 709-715.

Mossman, J., Patrick, A.D. (1982). Prenatal diagnosis of Mucopolysaccharidosis by twodimensional electrophoresis of amniotic fluid glycosaminoglycans, Prenat. Diagn., 2, 169-176.

Singh, G., DiFerrante, N., Niebes, P., Tavella, D. (1976). N-Acetylgalactosamine-6-sulfate sulfatase in man. Absence of the enzyme in Morquio disease, J. Clin. Invest., 57, 1036-1040.

Sinith, P.K., Krohn, R.J., Hermanson, G.T., Mallia, A.K., Gartner, F.H., Provenzano Fujumoto, E.K., Goeke, N.M., Olson, B.J., Klenk, D.C. (1985). Measurement of protein using bicinchonic acid, Anal. Biochem., 150, 76-85.

Van Diggelen, O.P., Zhao, H., Kleijer, W.J., Janse, H.C., Poorthuis, B. J. H. M., van Pelt, J., Kamerling, J.P., Galjaard, H. (1990). A fluorimetric enzyme assay for the diagnosis of Morquio disease type A (MPS IV A), Clin. Chim. Acta, in press.

Yutaka, T., Okada, S., Kato, T., Inui, K., Yabuuhi, H. (1982). Galactose-6-sulphate sulphatase activity in Morquio syndrome, Clin. Chim. Acta, 122, 169-180. 